\title{
UNIFIED THEORY OF ACCEPTANCE AND USE OF TECHNOLOGY: THE ADOPTION OF MOBILE MESSAGING APPLICATION***
}

According to Turkish Statistical Institute, 96.8\% of households have mobile phones and smart phones. While mobile penetration was 1\% in 1995, it reached 73\% in 2014. Opening account of social media, messaging and chatting is the first activity in mobile phone users in Turkey. Consequently, understanding the main determinants of technology acceptance behavior is an important issue for both academicians and practitioners. Therefore, the aim of this study is to test the model of the adoption of mobile messaging applications, especially fast messaging. The framework of Unified Theory of Acceptance and Use of Technology (UTAUT) was used in the paper. For testing our hypotheses, questionnaires were given to people having mobile devices and mobile internet users. Our data was collected by convenience sampling method. The research hypotheses were tested by structural equation modeling (SEM). The results indicated that there were strong relationships among the research variables. Finally, theoretical and managerial implications of the study findings are discussed.

Keywords: Adoption of Mobile Messaging, Mobile Messaging, Unified Theory of Acceptance and Use of Technology (UTAUT), Turkey.

Associate Professor Hanifi Murat Mutlu, PhD

Gaziantep University, Department Of International Trade and Logistics, Gaziantep, Turkey; email:mmutlu@gantep.edu.tr.

** Ali Der, M.Sc.; Graduated from Department Of International Trade and Logistics, Gaziantep University, Gaziantep, Turkey; email: alimuratder@yahoo.com

$* * *$ An earlier version of this paper was presented at $14^{\text {th }}$ International Scientific Conference on Economic and Social Development, May 2016, Belgrade, Serbia] 


\section{Introduction}

The report of Centre of Retail Research points out that mobile e-commerce is the fastest growing trade ${ }^{1}$. In 2014, total e-commerce via mobiles in Europe was $€ 23.77$ billion, moreover online retailing as a percentage of all retail sales is now $12.7 \%$, but this percentage is expected to reach $21.5 \%$. Mobile application market has a very important position in mobile e-commerce. According to a report of the Markets and Markets, the total global mobile applications market is expected to be worth US $\$ 25.0$ billion by 2015 ; hence the global market is expected to record a CAGR (compound annual growth rate) of $29.6 \%$ from 2010 to $2015^{2}$. The report of e Marketer Inc. predicted that mobile phone messaging applications will be used by more than 1.4 billion consumers in 2015 and the growth in popularity of messaging applications will reach 2 billion users and represent $80 \%$ of smart phone users by 2018 worldwide ${ }^{3}$. In the light of these emerging developments, we aim to examine determinants of mobile message adoption and do it under the framework of UTAUT. The research question is raised: What factors influence the behavior intention and the use of mobile messaging adoption? Williams, Rana, and Dwivedi ${ }^{4}$, made a systematic literature review in ISI Web of Knowledge and Google Scholar on UTAUT from 2004 to June 2011. They found 174 usable research papers. Their findings reveal that UTAUT research had been based on results from 41 countries, but none of this research collected Turkish sample.

This paper offers three main contributions to the literature. Firstly, UTAUT-2 model has been considered less than model 1 in diffusion literature. The study contributes to the extension of UTAUT-2 model. This research tries to complete this gap. Secondly, the determinants of adoption of any mobile applications in Turkish consumers -emerging economy- can be analyzed and as a result it will provide better knowledge for the diffusion and adoption of literature. Finally, the study focuses on the adoption of specific application that is very intensive in the daily life. So, the results of this study are important for both academicians and practitioners.

$1 \quad$ Centre of RetailResearch (2016):Online Retailing: Britain, Europe, US andCanada 2015. Retrieved 29.03.2016 from http://www.retailresearch.org/onlineretailing.php

2 MarketsandMarkets (2016): World Mobile Applications Market Worth US\$25 Billionby 2015. Retrieved 29.03.2016 from http://www.marketsandmarkets.com/PressReleases/ mobile-applications-market.asp

3 eMarketer Inc. (2015). Mobile Messaging to Reach 1.4BillionWorldwide in 2015. Retrieved 29.03.2016 from http://www.emarketer.com/Article/Mobile-Messaging-Reach-14-BillionWorldwide-2015/1013215\#sthash.Sx3sNjo9.dpuf

4 Williams, M.D., Rana, N.P., and Dwivedi, Y.K. (2015). The unified theory of acceptance and use of technology (UTAUT): a literature review. Journal of Enterprise Information Management, 28(3), 443-488. 


\section{Literature}

Both academicians and practitioners are interested in understanding the main determinants of technology acceptance behavior. Venkatesh et. al..$^{5}$ proposed UTAUT as an acceptance model after a comprehensive assessment of eight prominent models used in user acceptance of technology ${ }^{6}$ :

1) The technology acceptance model (TAM) by Davis ${ }^{7}$

2) The theory of reasoned action (TRA) by Fishbein and Ajzen ${ }^{8}$

3) The theory of planned behavior (TPB) by Ajzen ${ }^{9}$

4) A model combining TAM and TPB (C-TAM-TPB) by Taylor and Todd $\left(1995 \mathrm{a}^{10}\right.$ and $\left.1995 \mathrm{~b}^{11}\right)$

5) The motivational model (MM) by Davis, Bagozzi, and Warshaw ${ }^{12}$

6) The model of PC utilization (MPCU) by Thompson, Higgins, and Howell ${ }^{13}$

7) Social cognitive theory (SCT) by Bandura ${ }^{14}$

8) The diffusion of innovation theory (DOI) by Rogers ${ }^{15}$

These theories were tested on the diffusion and adoption of several new products or services. Moreover, some of these models focus on the adoption of information and communication technologies in particular. Venkatesh et. al. ${ }^{16}$

Venkatesh et. al. (2003). User acceptance of information technology: Toward a unified view. MIS Quarterly, 425-478.

6 Singeh, F.W., Abrizah, A., and Harun Abdul Karim, N. (2013). Malaysian authors' acceptance to self-archive in institutional repositories: Towards a unified view. The Electronic Library, 31(2), 188-207. p.190

7 Davis, F.D. (1986). A technology acceptance model for empirically testing new end-user information systems: theory and result. Ph.D. dissertation, Sloan School of Management, Massachusetts Institute of Technology.

$8 \quad$ Fishbein, M. and Ajzen I. (1975). Belief, Attitude, Intention and Behavior: An Introduction to Theory and Research, MA: Addision-Wesley.

9 Ajzen, I. (1991). The theory of planned behavior. Organizational behavior and human decision processes, 50 (2), 179-211.

10 Taylor, S., and Todd, P. (1995a). Assessing IT Usage: The Role of Prior Experience. MIS Quarterly, 19, 561-570.

11 Taylor, S., and Todd, P.A. (1995b). Understanding information technology usage: A test of competing models. Information systems research, 6(2), 144-176

12 Davis, F. D., Bagozzi, R. P., and Warshaw, P. R. (1992). Extrinsic and intrinsic motivation to use computers in the workplacel. Journal of applied social psychology, 22(14), 1111-1132.

13 Thompson, R. L., Higgins, C. A., and Howell, J. M. (1991). Personal computing: Toward a conceptual model of utilization. MIS Quarterly, 125-143.

14 Bandura, A. (1986). Social Foundations of Thought and Action: A Social Cognitive Theory, NJ: Prentice Hall.

15 Rogers, E.M. (1962). Diffusion of Innovations, NY: Free Press.

16 Venkatesh et. al. (2003) 
developed a new model by synthesizing eight models focusing on information and communication technologies in particular. This model is named the "Unified Theory of Acceptance and Use of Technology (UTAUT)". This model identifies performance expectancy (PE), effort expectancy (EE), social influence (SI) and facilitating conditions (FC) as direct determinants of behavioral intention and use behavior. The four variables (PE, EE, SI, and FC) directly affect intention and these variables, age, gender, experience and being voluntary directly affect the use $\mathrm{e}^{17}$. UTAUT-2 was developed in $2012^{18}$. It is the extended form of UTAUT. UTAUT-2 added the following new variables to the model; its analysis unit focuses on user acceptance and use; Hedonic motivation (HM), Price-value (PV) and Habit (HB). The developer of UTAUT-2 asserted that Model-2 is better than Model-1, as the percentage of variance is explained in both intention and use $^{19}$. Escobar-Rodriguez and Carvajal-Trujillo investigated the studies focusing on the UTAUT in consumer contexts including the adoption of the following information and communication technologies by users, given in Table $1^{20}$.

The conceptual model of this study based on UTAUT-2 and the relationship among the research variables is given in figure 1.

Performance expectancy (PE) has been substituted by perceived usefulness among the construct of TAM. PE is defined as the degree to which on individual believes the system would be beneficial to his/her job performance ${ }^{21}$. Zuiderwijk, Janssen, and Dwivedi ${ }^{22}$ tested a modified model based on the UTAUT, used to empirically determine predictors influencing the acceptance and use of open data technologies. They posited that PE directly and positively influenced the intention to use and accept open data technologies. PE is one of the highest explanatory powers of variables on behavioral intention $(\mathrm{BI})^{23}$. Hew et. al. found that PE had a significant effect on BI to use mobile applications ${ }^{24}$. Der and Mutlu asserted

Ibid., p. 447

18 Venkatesh, V., Thong, J. Y., and Xu, X. (2012). Consumer acceptance and use of information technology: extending the unified theory of acceptance and use of technology. MIS Quarterly, 36(1), 157-178.

19 Ibid.

20 Escobar-Rodriguez, T., and Carvajal-Trujillo, E. (2014). Online purchasing tickets for low cost carriers: An application of the unified theory of acceptance and use of technology (UTAUT) model. Tourism Management, 43, 70-88.

$21 \quad$ Venkatesh et. al. (2003)

22 Zuiderwijk, A., Janssen, M., and Dwivedi, Y. K. (2015). Acceptance and use predictors of open data technologies: Drawing upon the unified theory of acceptance and use of technology. Government Information Quarterly, 32(4), 429-440.

23 Helena Chiu, Y. T., Fang, S. C., and Tseng, C. C. (2010). Early versus potential adopters: Exploring the antecedents of use intention in the context of retail service innovations. International Journal of Retail and Distribution Management, 38(6), 443-459.

24 Hew et. al. (2015). What catalyses mobile apps usage intention: an empirical analysis. Industrial Management and Data Systems, 115(7), 1269-1291. 
that PE positively affects $\mathrm{BI}$ on mobile shopping ${ }^{25}$. Al-Qeisi et. al. explored the link between website design quality and PE on Internet Banking Usage and found that PE had indirect effect on website design quality perceptions ${ }^{26}$.

Table 1: Examples of applications of the UTAUT

\begin{tabular}{|c|c|}
\hline Applications & Authors \\
\hline Mobile banking & $\begin{array}{c}\text { Zhou, Lu, and Wang, 2010; Baptista and } \\
\text { Oliveira, 2015 }\end{array}$ \\
\hline Mobile payment & $\begin{array}{c}\text { De Sena Abrahaoa, Moriguchib and Andrade, } \\
\text { 2016 }\end{array}$ \\
\hline Mobile phone technologies & $\begin{array}{c}\text { Lu, Yao, and Yu, 2005; Park, Yang, and Lehto, } \\
\text { 2007; Wang and Wang, 2010; Zhou, 2011 }\end{array}$ \\
\hline Mobile shopping & Der and Mutlu, 2015 \\
\hline Online family dispute resolution services & Casey and Wilson-Evered,2012 \\
\hline Location-based services & Xu and Gupta, 2009 \\
\hline Question answer services & Deng, Liu, and Qi, 2011 \\
\hline & $\begin{array}{c}\text { Abushanab and Pearson, 2007; Im, Hong, } \\
\text { and Kang, 2011; Riffai, Grant, and Edgar, 2012; } \\
\text { Al-Qeisi et. al., 2014; Martins, Oliveira and } \\
\text { Popovic, 2014 }\end{array}$ \\
\hline Internet banking & Chiu and Wang, 2008 \\
\hline Virtual learning technologies & Sapio et. al., 2010; Schaupp, Carter, and \\
\hline & McBride, 2010; Wang and Shih, 2009; \\
\hline E-government & Tosuntas, Karadadag and Orhan (2015) \\
\hline E-recruiting & San Martin and Herrero, 2012 \\
\hline Online purchase intention in regard to & Escobar-Rodriguez and Carvajal-Trujillo, 2014 \\
\hline Online ticket & Zuiderwijk, Janssen, and Dwivedi (2015) \\
\hline Open data technologies & \\
\hline
\end{tabular}

(Source: The table developed by Escobar-Rodriguez and Carvajal-Trujillo, 2014).

Effort expectancy (EE) is the degree of ease of technology use ${ }^{27}$. EE is based on perceived ease of use from TAM. Researchers found a positive relationship

25 Der A. and Mutlu H.M. (2015). The Adoption of Mobile Shopping in Turkish Consumer. International Academic Conference Management, Economics and Marketing.

26 Al-Qeisi et. al. (2014). Website design quality and usage behavior: Unified Theory of Acceptance and Use of Technology. Journal of Business Research, 67(11), 2282-2290.

27 Venkatesh, Thong, and $\mathrm{Xu},(2012)$, pp. 159-162 
between $\mathrm{EE}$ and $\mathrm{BI}^{28}$. De Sena Abrahaoa, Moriguchi and Andrade showed that the PE, EE, SI and perceived risk explained $76.2 \%$ of the variance of the intention of adoption of mobile payment and the four factors had significant effect on the adoption $^{29}$. Tsourela and Roumeliotis found strong relationships between the PE, $\mathrm{EE}, \mathrm{SI}$ and FC and BI in technology-based services ${ }^{30}$. Awwad and Al-Majali empirically exhibited that $\mathrm{BI}$ depended on $\mathrm{PE}, \mathrm{EE}$, and SI in the context of electronic library services in public Jordanian universities ${ }^{31}$. The results of Teo and Noyes' papers demonstrated that $\mathrm{PE}, \mathrm{EE}$ and SI were significant determinants of $\mathrm{BI}$ on technology in trainee teachers ${ }^{32}$.

Social influence (SI) is defined as "the degree to which on individual perceives that important others (family and friends) believe he or she should use the new system ${ }^{33 \text {. }}$. Defined as recommendation of the people considered important to use the new technology $y^{34}$, social influence (SI) assumes that these persons will create positive influence on the adoption through these people's influencing the individual. $\mathrm{Wu}$, Tao and Yang argued that PE, SI and FC of $3 \mathrm{G}$ mobile telecommunication services had positive influence towards $\mathrm{BI}^{35}$.

Facilitating conditions (FC) is the degree of belief in the fact that individual's organizational and technical infrastructure system is available/ready to sup-

28 Such as: (1) Martins, C., Oliveira, T., and Popovič, A. (2014). Understanding the Internet banking adoption: A unified theory of acceptance and use of technology and perceived risk application. International Journal of Information Management, 34(1), 1-13. (2) Oechslein, O., Fleischmann, M., and Hess, T. (2014, January). An Application of UTAUT2 on Social Recommender Systems: Incorporating Social Information for Performance Expectancy. InSystem Sciences (HICSS), 2014 47th Hawaii International Conference on(pp. 32973306). IEEE. (3) Nistor et. al. (2014). Participation in virtual academic communities of practice under the influence of technology acceptance and community factors. A learning analytics application. Computers in Human Behavior,34, 339-344. (4) Escobar-Rodriguez and Carvajal-Trujillo, 2014.

29 De Sena Abrahão, R., Moriguchi, S. N., and Andrade, D. F. (2016). Intention of adoption of mobile payment: An analysis in the light of the Unified Theory of Acceptance and Use of Technology (UTAUT). RAI Revista de Administração e Inovação, 13(3), 221-230.

30 Tsourela, M., and Roumeliotis, M. (2015).The moderating role of technology readiness, gender, and sex in consumer acceptance and actual use of Technology-based services. The Journal of High Technology Management Research, 26(2), 124-136.

31 Awwad, M. S., and Al-Majali, S. M. (2015). Electronic library services acceptance and use: an empirical validation of unified theory of acceptance and use of technology. The Electronic Library, 33(6), 1100-1120.

32 Teo, T., and Noyes, J. (2014). Explaining the intention to use technology among preservice teachers: a multi-group analysis of the Unified Theory of Acceptance and Use of Technology. Interactive Learning Environments, 22(1), 51-66.

33 Venkatesh et. al. (2003), p. 451

34 Venkatesh, Thong, and $\mathrm{Xu}, 2012$, pp. 159-162

$35 \mathrm{Wu}, \mathrm{Y}$. L., Tao, Y. H., and Yang, P. C. (2008). The use of unified theory of acceptance and use of technology to confer the behavioral model of $3 \mathrm{G}$ mobile telecommunication users. Journal of Statistics and Management Systems, 11(5), 919-949. 
port the use of innovation ${ }^{36}$. Venkatesh et. al. defined FC as the degree to which an individual believes that an organization and technical infrastructure is capable of supporting the system ${ }^{37}$. FC affects both the behavioral intention and use.

Hedonic motivation (HM) is the first variable added to the UTAUT-2. HM is defined as "the fun or pleasure derived from using a technology" ${ }^{38}$. HM refers to the enjoyment or happiness resulting from using a technology. HM plays an important role in BI for individual's acceptance of a technology ${ }^{39}$. Baptista and Oliveira hypothesized the relationships between the constructs of UTAUT-2 model and mobile banking BI and use behavior ${ }^{40}$. They found that PE, HM, PV, and $\mathrm{HB}$ directly and significantly affect on BI.

UTAUT-1 was developed to adopt the system/innovation in the organizational structure. However, there are significant differences between the consumer use and organizational use. Cost and pricing may have a significant effect on individual's acceptance of technology. For this reason, Venkatesh et. al. added Price value (PV) variable to the model. They defined PV as "consumers' cognitive tradeoff between the perceived benefits of the applications and the monetary cost of using them"41.

Habit (HB) has been defined as "the extent to which people tend to perform behaviors automatically because of learning...”, “...HB is viewed as prior behavior and is measured as the extent to which an individual believes that behavior to be automatic"s2.

By taking into account the framework of UTAUT-1 model, a recent paper found out the following results. Yang tested UTAUT model on 400 mobile services users ${ }^{43}$. He found that $\mathrm{PE}, \mathrm{SI}$, and FC were positively related to BI regarding the use of mobile shopping services. Wong, Russo, and McDowall showed that $\mathrm{PE}$ and $\mathrm{EE}$ had a direct and statistically significant positive effect on $\mathrm{BI}^{44}$. According to Deng, Liu, and Qi, PE and EE positively related to $\mathrm{BI}$, on the other

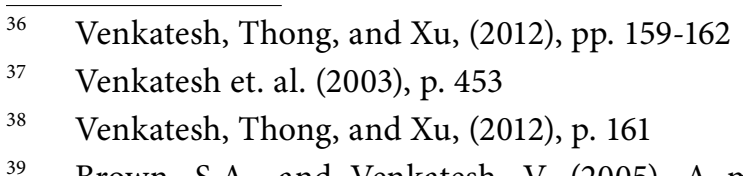

39 Brown, S.A., and Venkatesh, V. (2005). A model of adoption of technology in the household: A baseline model test and extension incorporating household life cycle. Management Information Systems Quarterly, 29(3), 4, 399-426.

40 Baptista, G., and Oliveira, T. (2015). Understanding mobile banking: The unified theory of acceptance and use of technology combined with cultural moderators. Computers in Human Behavior, 50, 418-430.

${ }^{41} \quad$ Venkatesh, Thong, and Xu, 2012, p. 161

42 Ibid.

${ }^{43}$ Yang, K. (2010). Determinants of US consumer mobile shopping services adoption: implications for designing mobile shopping services. Journal of Consumer Marketing, 27(3), 262-270.

44 Wong, K. T., Russo, S., and McDowall, J. (2013). Understanding early childhood student teachers' acceptance and use of interactive whiteboard. Campus-Wide Information Systems, 30(1), 4-16. 
hand, FC related to the actual use on the web-based question-answer services adoption $^{45}$. Awwad and Al-Majali established that BI on electronic library services depended on $\mathrm{PE}, \mathrm{EE}$, and SI, while use behavior depended on $\mathrm{FC}^{46}$. While FC had a significant effect on use behavior, PE and SI had a significant effect on $\mathrm{BI}$, but not on $\mathrm{EE}^{47}$. Lwoga and Kombo investigated the major predictors of actual usage of an e-learning system, but they did not find significant positive relationships between the main factors: PE, EE, FC and SI and the actual use ${ }^{48}$.

Given the recent paper on UTAUT-2 model, Hew et. al. found that PE, EE, FC, HB, HM had significant effect on BI to use mobile applications ${ }^{49}$. Gao, $\mathrm{Li}$, and Luo made an empirical study on wearable technology acceptance and they showed that PE, HM, EE, SI were positively associated with individual's intention to adopt healthcare wearable devices ${ }^{50}$. According to a study made by Wong et. al., EE, SI, FC, HM, and HB had a significant impact on BI to adopt mobile TV ${ }^{51}$. Oechslein, Fleischmann, and Hess developed UTAUT-2 model based framework in acceptance of social recommender systems ${ }^{52}$. They found that PE, EE, SI and $\mathrm{HB}$ positively influenced but FC had a negative effect on BI. Therefore, HM and PV were non-significant. In a study conducted on UTAUT-2, PE, EE, PV, and $\mathrm{HB}$ were found to have significant effects on BI for elderly people' adoptions of Internet banking ${ }^{53}$. Moroson and DeFranco detected that PE, SI, HM, HB were significant at $\mathrm{p}<.001$ and FC were significant at $\mathrm{p}<.05^{54}$. Williams, Rana, and Dwivedi showed the relationships between major UTAUT variables in Table $2^{55}$.

$\overline{45}$ Deng, S., Liu, Y., and Qi, Y. (2011). An empirical study on determinants of web based question-answer services adoption. Online information Review, 35(5), 789-798.

46 Awwad and Al-Majali, (2015).

47 Chang et. al. (2015). Exploration of usage behavioral model construction for university library electronic resources. The Electronic Library, 33(2), 292-307.

48 Lwoga, E. T., and Komba, M. (2015). Antecedents of continued usage intentions of webbased learning management system in Tanzania. Education+ Training, 57(7), 738-756.

$49 \quad$ Hew et. al. (2015)

50 Gao, Y., Li, H., and Luo, Y. (2015). An empirical study of wearable technology acceptance in healthcare. Industrial Management and Data Systems, 115(9), 1704-1723.

$51 \quad$ Wong et. al. (2014). Mobile TV: a new form of entertainment? Industrial Management and Data Systems, 114(7), 1050-1067.

52 Oechslein, O., Fleischmann, M., \& Hess, T. (2014, January). An application of UTAUT2 on social recommender systems: Incorporating social information for performance expectancy. In 2014 47th Hawaii International Conference on System Sciences (pp. 32973306). IEEE.

53 Arenas-Gaitán, J. O. R. G. E., Peral, B., and Jerónimo, M. A. (2015). Elderly and Internet Banking: An Application of UTAUT2. Journal of Internet Banking and Commerce, 20(1).

54 Morosan, C.,and DeFranco, A. (2016). It's about time: Revisiting UTAUT2 to examine consumers' intentions to use NFC mobile payments in hotels. International Journal of Hospitality Management, 53, 17-29.

55 Williams, M. D., Rana, N. P., and Dwivedi, Y. K, (2015) 
Table 2: Relationships between major UTAUT variable

\begin{tabular}{|c|c|c|c|c|c|c|}
\hline Relations & PE-BI & EE-BI & SI-BI & FC-BI & FC-U & BI-U \\
\hline Significant relation & 93 & 64 & 86 & 32 & 36 & 49 \\
\hline Non-significant relation & 23 & 46 & 29 & 15 & 18 & 11 \\
\hline Negative relation & 0 & 0 & 0 & 1 & 0 & 1 \\
\hline Not tested & 33 & 39 & 34 & 101 & 95 & 86 \\
\hline
\end{tabular}

(Source: Williams, Rana, and Dwivedi, 2015)

In the light of these researches, we determined our hypotheses:

$\mathrm{H}_{1}$ : PE has a positive direct effect on $\mathrm{BI}$ in the use of mobile message applications. $\mathrm{H}_{2}$ : EE has a positive direct effect on $\mathrm{BI}$ in the use of mobile message applications. $\mathrm{H}_{3}$ : $\mathrm{SI}$ has a positive direct effect on $\mathrm{BI}$ in the use of mobile message applications. $\mathrm{H}_{4}$ : $\mathrm{FC}$ has a positive direct effect on $\mathrm{BI}$ in the use of mobile message applications. $\mathrm{H}_{5}: \mathrm{HM}$ has a positive direct effect on $\mathrm{BI}$ in the use of mobile message applications. $\mathrm{H}_{6}: \mathrm{PV}$ has a positive direct effect on $\mathrm{BI}$ in the use of mobile message applications. $\mathrm{H}_{7}$ : $\mathrm{HB}$ has a positive direct effect on $\mathrm{BI}$ in the use of mobile message applications. $\mathrm{H}_{8}$ : $\mathrm{BI}$ has a positive direct effect on Use.

\section{Method}

The data used in the study was collected along with second author's master thesis. Respondents filled in the second questionnaire form. While the first form measured adoption of mobile shopping, the second form was used for evaluation of the adoption of mobile messaging applications. Our population was required to have a smart phone, tablet computer or laptop and mobile Internet users, age +18 . Convenience sampling method was used in the study. We collected 344 questionnaires.

The conceptual model was based on UTAUT- 2 model $^{56}$. The research variables were adapted from in UTAUT model 1 and 2 and applied double translation process. PE, EE, SI, HM, PV, HB and BI measured 3 items while only FC consisted of 4 items. The total number of items was 28 . All constructs are measured using multiple-item, five-point scales with anchors ranging from Strongly Disagree (=1) to Strongly Agree (=5). Reliability of research constructs are sufficient according to Nunnally who suggests that Coronbach's Alpha value of 0.70 or better ${ }^{57}$. All constructs demonstrated acceptable reliability scores which is shown in Table 3.

\footnotetext{
$56 \quad$ Venkatesh, Thong, and $\mathrm{Xu},(2012)$

57 Nunnally, J. C. (1978). Psychometric theory (2th ed.). New York: McGraw-Hill. p.245.
} 


\section{Analysis}

Table 3 shows the means, standard deviations, Coronbach's Alpha, and bivariate Pearson correlations of the constructs. We found positive and strong correlations between $\mathrm{BI}$ and determinants of mobile messaging adoption.

Table 3: Correlation Analyses

\begin{tabular}{|c|c|c|c|c|c|c|c|c|c|c|c|c|c|}
\hline & $\begin{array}{c}1 \\
\mathrm{FC}\end{array}$ & $\begin{array}{c}2 \\
\mathrm{PE}\end{array}$ & $\begin{array}{c}3 \\
\mathrm{EE}\end{array}$ & $\begin{array}{c}4 \\
\mathrm{SI}\end{array}$ & $\begin{array}{c}5 \\
\mathrm{HM}\end{array}$ & $\begin{array}{c}6 \\
\mathrm{PV}\end{array}$ & $\begin{array}{c}7 \\
\mathrm{HB}\end{array}$ & $\begin{array}{c}8 \\
\mathrm{BI}\end{array}$ & $\begin{array}{c}9 \\
\text { USE }\end{array}$ & $\begin{array}{c}10 \\
\text { Age }\end{array}$ & $\begin{array}{l}\text { a } \\
\text { Mean }\end{array}$ & SD \\
\hline 1 & 1 & & & & & & & & & & .90 & 3.77 & .93 \\
\hline 2 & $.659^{* *}$ & 1 & & & & & & & & & .84 & 3.64 & .95 \\
\hline 3 & $.786^{* *}$ & $.702^{* *}$ & 1 & & & & & & & & .92 & 3.78 & .97 \\
\hline 4 & $.571^{* *}$ & $.554^{* *}$ & $.547^{* *}$ & 1 & & & & & & & .85 & 3.29 & .95 \\
\hline 5 & $.626^{* *}$ & $.621^{* *}$ & $.607^{* *}$ & $.492^{* *}$ & 1 & & & & & & .91 & 3.50 & .99 \\
\hline 6 & $.661^{* *}$ & $.607^{* *}$ & $.600^{* *}$ & $.474^{* *}$ & $.692^{* *}$ & 1 & & & & & .89 & 3.62 & .99 \\
\hline 7 & $.377^{* *}$ & $.416^{* *}$ & $.411^{* *}$ & $.441^{* *}$ & $.555^{* *}$ & $.448^{* *}$ & 1 & & & & .86 & 2.85 & 1.09 \\
\hline 8 & $.652^{* *}$ & $.689^{* *}$ & $.650^{* *}$ & $.550^{* *}$ & $.676^{* *}$ & $.636^{* *}$ & $.655^{* *}$ & 1 & & & .88 & 3.47 & .99 \\
\hline 9 & $.393^{* *}$ & $.324^{* *}$ & $.349^{* *}$ & $.340^{* *}$ & $.487^{* *}$ & $.413^{* *}$ & $.508^{* *}$ & $.464^{* *}$ & 1 & & .81 & 2.84 & 1.01 \\
\hline 10 & $-.179^{* *}$ & $-.199^{* *}$ & $-.231^{* *}$ & $-.148^{* *}$ & $-.231^{* *}$ & $-.224^{* *}$ & $-.341^{* *}$ & $-.204^{* *}$ & $-.308^{* *}$ & 1 & - & 29.62 & 7.81 \\
\hline
\end{tabular}

Structural equation model (SEM) was used to test research the hypothesis. Hair et. al. suggested a set of fit indices used to examine the structural model ${ }^{58}$. As shown in Table 4, chi2/df (the ratio between Chi-square and degrees of freedom), AGFI (Adjusted Goodness of Fit Index), CFI (comparative fit index), and RMR (root mean square residual) of the model fit indices exceed the respective common acceptance but obtain value of GFI (goodness of fit index), NFI (normed fit index), RFI (relative fit index), and RMSEA (root mean square error of approximation) indices had a very closely acceptable level.

Table 4: Model Fix Indices

\begin{tabular}{|c|c|c|}
\hline Model fit indices & Threshold & Obtained value \\
\hline chi $^{2} /$ df(the ratio between Chi-square and degrees of freedom) & $<3$ & 2.290 \\
\hline GFI (goodness of fit index) & $>0.9$ & 0.855 \\
\hline AGFI(Adjusted Goodness of Fit Index) & $>0.8$ & 0.818 \\
\hline CFI (comparative fit index) & $>0.9$ & 0.939 \\
\hline NFI (normed fit index) & $>0.9$ & 0.897 \\
\hline$R M R$ (root mean square residual) & $<0.08$ & 0.070 \\
\hline$R F I$ (relative fit index) & $>0.9$ & 0.879 \\
\hline$R M S E A$ (root mean square error of approximation) & $<0.05$ & 0.064 \\
\hline
\end{tabular}

58 Hair et. al. (2010), Multivariate Data Analysis, 7th ed., Prentice Hall, Upper Saddle River, NJ. 
In this study, $\mathrm{PE}(\beta=.387, \mathrm{p}<0.001), \mathrm{HB}(\beta=.430, \mathrm{p}<0.001)$ and $\mathrm{FC}(\beta=.211$, $\mathrm{p}<0.05)$ have a direct effect on BI. BI directly and positively affects behavior use $(\beta=.523, \mathrm{p}<0.001)$. Empirical research shows that $\mathrm{H}_{1}, \mathrm{H}_{4}, \mathrm{H}_{7}$ and $\mathrm{H}_{8}$ are supported. Overall, the model constructed in this study is shown in Figure 1.

\section{Figure 1: The Conceptual Model and Structural model results}

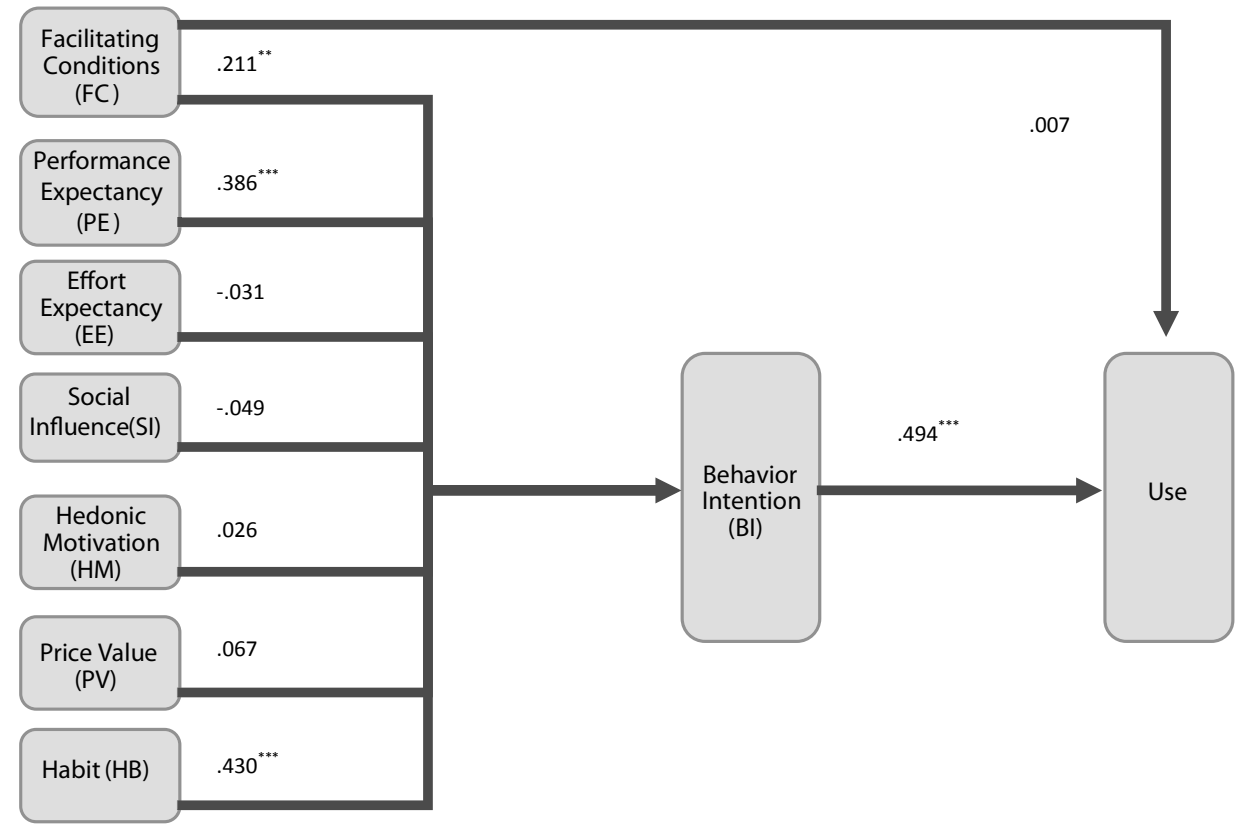

\section{Conclusion}

This study is based on the theory of adoption and diffusion of innovation. Among the main models and theories in the literature on diffusion and adoption of innovation, we preferred to use the framework of UTAUT-2 model. UTAUT-2 model is suitable to explain consumer' adoption process. We found that PE, EE, and HB play a crucial role in the adoption of mobile messaging applications. Regarding PE and EE, the findings match up with TAM. Mobile message applications have user friendly features - easy use- and usefulness -simple and hasslefree-for customer ${ }^{59}$. HB was found the most important determinant of adoption of mobile message applications. In literature, HB usually has a significant and positive effect on adoption of mobile or online innovations ${ }^{60}$. Venkatesh,

\footnotetext{
59 Teo et. al. (2015). The effects of convenience and speed in m-payment. Industrial Management and Data Systems,115(2), 311-331.

60 Such as; (1) Gao, Li, and Luo, 2015; (2) Wong et. al., 2014; (3) Escobar-Rodriguez and Carvajal-Trujillo, 2014
} 
Thong and $\mathrm{Xu}$ stressed that there is a significant and strong effect of consumer's habit on personnel technology use. Therefore, decision makers consider the link between habit and behavior and use ${ }^{61}$.

This study has several limitations. The first limitation is the direct effects among variables but this has not been discussed in indirect, mediating, and moderator effects. The second limitation is sample method.

\section{Literature}

- Abushanab, E., and Pearson, J. M. (2007). Internet banking in Jordan: the unified theory of acceptance and use of technology (UTAUT) perspective. Journal of Systems and Information Technology, 9(1), 78-97.

- Ajzen, I (1991). The Theory of Planned Behavior. Organizational Behavior and Human Decision Processes, 50, 179-211.

- Al-Qeisi, K., Dennis, C., Alamanos, E., and Jayawardhena, C. (2014). Website design quality and usage behavior: Unified Theory of Acceptance and Use of Technology. Journal of Business Research, 67(11), 2282-2290.

- Arenas-Gaitán, J. O. R. G. E., Peral, B., and Jerónimo, M. A. (2015). Elderly and Internet Banking: An Application of UTAUT2. Journal of Internet Banking and Commerce, 20(1).

- Awwad, M. S., and Al-Majali, S. M. (2015). Electronic library services acceptance and use: an empirical validation of unified theory of acceptance and use of technology. The Electronic Library, 33(6), 1100-1120.

- Bandura, A. (1986). Social Foundations of Thought and Action: A Social Cognitive Theory, NJ: Prentice Hall.

- Baptista, G., and Oliveira, T. (2015). Understanding mobile banking: The unified theory of acceptance and use of technology combined with cultural moderators. Computers in Human Behavior, 50, 418-430.

- Brown, S. A., and Venkatesh, V. (2005). A model of adoption of technology in the household: A baseline model test and extension incorporating household life cycle. Management Information Systems Quarterly, 29(3), 4, 399-426.

- Casey, T., and Wilson-Evered, E. (2012). Predicting uptake of technology innovations in online family dispute resolution serviced: an application and extension of the UTAUT. Computers in Human Behavior, 28(6), 2034-2045.

- Centre of RetailResearch (2016):Online Retailing: Britain, Europe, US and Canada 2015. Retrieved 29.03.2016 from http://www.retailresearch.org/onlineretailing.php

- $\quad$ Chang, S. S., Lou, S. J., Cheng, S. R., and Lin, C. L. (2015).Exploration of usage behavioral model construction for university library electronic resources. The Electronic Library, 33(2), 292-307.

61 Venkatesh, Thong, and $\mathrm{Xu}, 2012$ 
- Chiu, C. M., and Wang, E. T. G. (2008). Understanding web-based learning continuance intention: the role of subjective task value. Information and Management, 45(3), 194-201.

- Davis, F. D. (1986). A technology acceptance model for empirically testing new end-user information systems: theory and result. Ph.D. dissertation, Sloan School of Management, Massachusetts Institute of Technology.

- Davis, F. D., Bagozzi, R. P., and Warshaw, P. R. (1992). Extrinsic and intrinsic motivation to use computers in the workplacel. Journal of applied social psychology, 22(14), 1111-1132.

- De Sena Abrahao, R., Moriguchi, S. N., and Andrade, D. F. (2016). Intention of adoption of mobile payment: An analysis in the light of the Unified Theory of Acceptance and Use of Technology (UTAUT). RAI Revista de Administração e Inovação, 13(3), 221-230.

- Deng, S., Liu, Y., and Qi, Y. (2011). An empirical study on determinants of web based question-answer services adoption. Online information Review, 35(5), 789-798.

- Der A. veMutlu H.M. (2015). The Adoption of Mobile Shopping in Turkish Consumer.International Academic Conference Management, Economics and Marketing.

- eMarketer Inc. (2015). Mobile Messaging to Reach 1.4 BillionWorldwide in 2015. Retrieved 29.03.2016 from http://www.emarketer.com/Article/MobileMessaging-Reach-14-Billion-Worldwide-2015/1013215\#sthash.Sx3sNjo9.dpuf

- Escobar-Rodriguez, T., and Carvajal-Trujillo, E. (2014). Online purchasing tickets for low cost carriers: An application of the unified theory of acceptance and use of technology (UTAUT) model. Tourism Management, 43, 70-88.

- Fishbein, M. and Ajzen I. (1975). Belief, Attitude, Intention and Behavior: An Introduction to Theory and Research, MA: Addision-Wesley.

- Gao, Y., Li, H., and Luo, Y. (2015). An empirical study of wearable technology acceptance in healthcare. Industrial Management and Data Systems, 115(9), 1704-1723.

- Hair, J.F., Black, W.C., Babin, B.J. and Anderson, R.E. (2010), Multivariate Data Analysis, 7th ed., Prentice Hall, Upper Saddle River, NJ.

- Helena Chiu, Y. T., Fang, S. C., and Tseng, C. C. (2010). Early versus potential adopters: Exploring the antecedents of use intention in the context of retail service innovations. International Journal of Retail and Distribution Management, 38(6), 443-459.

- Hew, J. J., Lee, V. H., Ooi, K. B., and Wei, J. (2015). What catalyses mobile apps usage intention: an empirical analysis. Industrial Management and Data Systems, 115(7), 1269-1291.

- Im, I., Hong, S., and Kang, M. S. (2011). An international comparison of technology adoption: testing the UTAUT model. Information and Management, 48(1), 1-8. 
- Laumer, S., Eckhardt, A., and Trunk, N. (2010). Do as your parents say? Analyzing IT adoption influencing factors for full and under age applicants. Information Systems Frontiers, 12(2), 169-183

- Lu, J., Yao, J. E., and Yu, C. S. (2005). Personal innovativeness, social influences and adoption of wireless internet services via mobile technology. Journal of Strategic Information Systems, 14(3), 245-268

- Lwoga, E. T., and Komba, M. (2015). Antecedents of continued usage intentions of web-based learning management system in Tanzania. Education+ Training, 57(7), 738-756.

- MarketsandMarkets (2016): World Mobile Applications Market Worth US \$25 Billion by 2015. Retrieved 29.03.2016 from http://www.marketsandmarkets.com/PressReleases/mobile-applications-market.asp

- Martins, C., Oliveira, T., and Popovič, A. (2014). Understanding the Internet banking adoption: A unified theory of acceptance and use of technology and perceived risk application. International Journal of Information Management, 34(1), 1-13.

- Morosan, C., and DeFranco, A. (2016). It's about time: Revisiting UTAUT2 to examine consumers' intentions to use NFC mobile payments in hotels. International Journal of Hospitality Management, 53, 17-29.

- Nistor, N., Baltes, B., Dascălu, M., Mihăilă, D., Smeaton, G., and TrăuşanMatu, Ş. (2014). Participation in virtual academic communities of practice under the influence of technology acceptance and community factors. A learning analytics application. Computers in Human Behavior, 34, 339-344.

- Nunnally, J. C. (1978). Psychometric theory (2th ed.). New York: McGraw-Hill.

- Oechslein, O., Fleischmann, M., \& Hess, T. (2014, January). An application of UTAUT2 on social recommender systems: Incorporating social information for performance expectancy. In 2014 47th Hawaii International Conference on System Sciences (pp. 3297-3306). IEEE.

- Oechslein, O., Fleischmann, M., and Hess, T. (2014, January). An Application of UTAUT2 on Social Recommender Systems: Incorporating Social Information for Performance Expectancy. InSystem Sciences (HICSS), 2014 47th Hawaii International Conference on(pp. 3297-3306). IEEE.

- $\quad$ Park, J., Yang, S., and Lehto, X. (2007).Adoption of mobile technologies for Chinese consumers. Journal of Electronic Commerce Research, 8(3), 196-206.

- Riffai, M. M. M. A., Grantb, K., and Edgarc, D. (2012). Big TAM in Oman: exploring the promise of on-line banking, its adoption by customers and the challenges of banking in Oman. International Journal of Information Management, 32(3), 239-250.

- Rogers, E.M. (1962). Diffusion of Innovations, NY: Free Press.

- San Martín, H., and Herrero, Á. (2012). Influence of the user's psychological factors on the online purchase intention in rural tourism: integrating innovativeness to the UTAUT framework. Tourism Management, 33(2), 341-350. 
- Sapio, B., Turk, T., Cornacchia, M., Papa, F., Nicolo, E., and Livi, S. (2010). Building scenarios of digital television adoption: a pilot study. Technology Analysis and Strategic Management, 22(1), 43-63.

- Schaupp, L. C., Carter, L., and McBride, M. E. (2010). E-file adoption: a study of US taxpayers' intentions. Computers in Human Behavior, 26(4), 636-644.

- Singeh, F.W., Abrizah, A., and Harun Abdul Karim, N. (2013). Malaysian authors' acceptance to self-archive in institutional repositories: Towards a unified view. The Electronic Library, 31(2), 188-207.

- Taylor, S., and Todd, P. (1995a).Assessing IT Usage: The Role of Prior Experience. MIS Quarterly, 19 (1995): 561-570.

- Taylor, S., and Todd, P.A. (1995b). Understanding information technology usage: A test of competing models. Information systems research, 6(2), 144-176.

- Teo, A. C., Tan, G. W. H., Ooi, K. B., Hew, T. S., and Yew, K. T. (2015). The effects of convenience and speed in m-payment. Industrial Management and Data Systems, 115(2), 311-331.

- Teo, T., and Noyes, J. (2014). Explaining the intention to use technology among pre-service teachers: a multi-group analysis of the Unified Theory of Acceptance and Use of Technology. Interactive Learning Environments, 22(1), 51-66.

- Thompson, R. L., Higgins, C. A., and Howell, J. M. (1991). Personal computing: Toward a conceptual model of utilization. MIS Quarterly, 125-143.

- Tosuntas, Ş. B., Karadag, E., and Orhan, S. (2015). The factors affecting acceptance and use of interactive whiteboard within the scope of FATIH project: A structural equation model based on the Unified Theory of acceptance and use of technology. Computers and Education, 81, 169-178.

- Tsourela, M., and Roumeliotis, M. (2015).The moderating role of technology readiness, gender, and sex in consumer acceptance and actual use of Technology-based services. The Journal of High Technology Management Research, 26(2), 124-136.

- Venkatesh, V., Morris, M. G., Davis, G. B., and Davis, F. D. (2003). User acceptance of information technology: Toward a unified view. MIS Quarterly, 425-478.

- Venkatesh, V., Thong, J. Y., and Xu, X. (2012). Consumer acceptance and use of information technology: extending the unified theory of acceptance and use of technology. MIS Quarterly, 36(1), 157-178.

- Wang, H. W., and Wang, S. H. (2010). User acceptance of mobile internet based on the unified theory of acceptance and use of technology: investigating the determinants and gender differences. Social Behavior and Personality: An International Journal, 33(3), 415-426.

- Wang, Y. S., and Shih, Y. W. (2009). Why do people use information kiosks? A validation of the unified theory of acceptance and use of technology. Government Information Quarterly, 26(1), 158-165. 
- Williams, M. D., Rana, N. P., and Dwivedi, Y. K. (2015). The unified theory of acceptance and use of technology (UTAUT): a literature review. Journal of Enterprise Information Management, 28(3), 443-488.

- Wong, C. H., Wei-Han Tan, G., Loke, S. P., and Ooi, K. B. (2014). Mobile TV: a new form of entertainment? Industrial Management and Data Systems, 114(7), 1050-1067.

- Wong, K. T., Russo, S., and McDowall, J. (2013). Understanding early childhood student teachers' acceptance and use of interactive whiteboard. Campus-Wide Information Systems, 30(1), 4-16.

- Wu, Y. L., Tao, Y. H., and Yang, P. C. (2008). The use of unified theory of acceptance and use of technology to confer the behavioral model of $3 \mathrm{G}$ mobile telecommunication users. Journal of Statistics and Management Systems, 11(5), 919-949.

- $\mathrm{Xu}, \mathrm{H}$., and Gupta, S. (2009). The effects of privacy concerns and personal innovativeness on potential and experienced customers' adoption of location-based services. Electronic Markets, 19(2e3), 137-149.

- Yang, K. (2010). Determinants of US consumer mobile shopping services adoption: implications for designing mobile shopping services. Journal of Consumer Marketing, 27(3), 262-270.

- Zhou, T. (2011). Understanding mobile internet continuance usage from the perspectives of UTAUT and flow. Information Development, 27(3), 207-218.

- Zhou, T., Lu, Y., and Wang, B. (2010). Integrating TTF and UTAUT to explain mobile banking user adoption. Computers in Human Behavior, 26(4), 760-767.

- Zuiderwijk, A., Janssen, M., and Dwivedi, Y. K. (2015). Acceptance and use predictors of open data technologies: Drawing upon the unified theory of acceptance and use of technology. Government Information Quarterly, 32(4), 429-440. 
Dr Hanifi Murat Mutlu, vanredni profesor

Fakultet za medunarodnu trgovinu i logistiku, Univerzitet Gaziantep, Turska Mr Ali Der,

Fakultet za medunarodnu trgovinu i logistiku, Univerzitet Gaziantep, Turska

\section{OBJEDINJENA TEORIJA PRIHVATANJA I UPOTREBE TEHNOLOGIJE: PRIHVATANJE APLIKACIJE MOBILNIH PORUKA}

Prema Turskom institutu za statistiku, 96.8\% domaćinstava ima mobilne i pametne telefone. Dok je zastupljenost mobilnih telefona iznosila 1\% 1995, 2014. godine ona je dostigla 73\%. Otvaranje naloga na društvenim mrežama, slanje poruka i ćaskanje su osnovne aktivnosti korisnika mobilnih telefona u Turskoj. Shodno tome, razumevanje glavnih determinanti ponašanja u vezi sa prihvatanjem tehnologija predstavlja važno pitanje, kako za naučnu zajednicu, tako i praksu. Zato je ciljovog istraživanja da testira model prihvatanja aplikacija mobilnih poruka, posebno brzih poruka. U radu je upotrebljen okvir Objedinjene teorije prihvatanja i upotrebe tehnologije (UTAUT). Za testiranje naših hipoteza ispitanicima koji imaju mobilne telefone $i$ koji su korisnici interneta putem telofona dati su upitnici.Podaci su prikupljeni metodom uzorkovanja. Hipoteze istraživanja su proverene modeliranjem strukturalne jednačine (SEM).Rezultati su potvrdili da postoji direktna veza među ispitanim varijablama.Na kraju rada je analiziran značaj rezultata za teoriju i menadžment.

Ključne reči: Prihvatanje mobilnih poruka, mobilne poruke, Objedinjena teorija prihvatanja i upotrebe tehnologije(UTAUT),Turska 